Article

\title{
Illuminating a Truth: Drșțānta and Huatou
}

\author{
Jeson Woo $\mathbb{D}$ \\ Department of Buddhist Studies, Dongguk University, Seoul 04620, Korea; jwoo@dongguk.edu
}

Received: 3 July 2020; Accepted: 21 August 2020; Published: 28 August 2020

check for updates

\begin{abstract}
In Chan/Seon/Zen (禪, hereafter referred to as Chan) Buddhism, the gongan (公案), a word that can be literally translated as "public case", is conceived as both the tool by which enlightenment is brought about and an expression of the enlightened mind itself. Among the diverse styles of gongan, perhaps the most puzzling is a form of its key phrase, huatou (話頭), that utilizes specific things in the world. These things are either real and empirically observable, or conversely, unreal and merely hypothetical. A typical example is the figure of the "cypress tree in the front yard". This paper tries to demonstrate that such a huatou has a structural similarity to the drștānta (喩), an element within the three-part syllogism of Buddhist logic, insomuch as it functions as an epistemic instrument for the disclosing of a truth.
\end{abstract}

Keywords: gongan; huatou; dṛștānta; xiancheng gongan

\section{The Gongan}

The idea that religious language, particularly in paradoxical and esoteric forms, brings about enlightenment is fundamental to most Chan texts. The phrase, "at these words, so and so was awakened" is perhaps the most common locution in late Tang to Song Chan literature (Wright 2000, p. 205). The term “these words" refers to what is called gongan (公案) in the Chan school. They are brief sayings, dialogues, or anecdotes that have been excerpted from the biographies and discourses of Chan patriarchs.

The term gongan literally translates as "public case" and is a precedent established by legal judgments. Just as the records of legal tradition deploy a certain criterion for justice into the public domain, so likewise do the "public cases" of the Chan tradition set up a criterion for awakening. Thus, gongans provide an authoritative standard of evaluation for the heuristic insights of Chan practitioners. They are meant to serve as an objective and universal principle through which all claims to the attainment of Buddhahood can be judged with discretion.

In early Chan history, the gongan developed with different implications for the Chan of wenzi (文字, literally “words and letters"), kanhua (看話, “looking into language"), or mozhao (默照, “silent illumination"). Among them, two distinctive concepts of gongan can be illustrated, depending on the meaning and role assigned to it in Chan training. ${ }^{1}$ On the one hand, the gongan is nothing more than an expedient for realizing one's own innate enlightenment (Buswell 1991, p. 346). It is precisely the key to building the "sensation of doubt" (iching, 疑情) for Chan students and steering their single-minded attention to the huatou (話頭), its punch line. As a contemplative tool for arriving at the place where there are no doubts, the gongan itself has no ultimate meaning (Buswell 1991, p. 348; Wright 2000, p. 208).

The gongan is, on the other hand, that which exposes reality directly and without distortion (Wright 2000, p. 202). It really corresponds to the way things are. The perfect form of enlightenment is

1 For the issues on the different interpretations of gongan, see Wright (2000, pp. 206-7). 
already connoted in the gongan. If meditatively pursued, its form could be traced back to the moment of its formation as manifesting a truth. ${ }^{2}$ In this respect, Chan masters employ the term xiancheng gongan (現成公案), which refers to the fundamental point that has to be actualized. ${ }^{3}$ As an object of realization in the practice of meditation, the gongan reveals a law or a universal principle, that is, a truth (Nishijima and Cross 2007, p. 41).

The two different aspects of gongan are not mutually exclusive but complementary. For instance, Japanese Zen master Dōgen Kogon (ca. 1200-53) deeply appreciates the gongan as an expedient to bring about enlightenment; yet, he also lends significance to its realization as absolute truth dynamically present in life (Kim 1985, p. 56).

\section{A Style of Gongan}

Traditionally, around 1700 gongans are said to have been in circulation in the Chan school. They are diverse in their styles. A characteristic example of a style is the well-known gongan, "When both hands come together in applause, a sound is produced; listen to the sound of one hand clapping". Yet mostly, a gongan is set in question-and-answer form, as in the question, "Does a dog have Buddha nature?" and its answer, "No".

Among the diverse styles of gongans, one of the most puzzling is those whose huatou (話頭), the key phrase in a gongan, embodies a specific thing. The following example is illustrative of how a huatou employs a real object.

Gongan 1 Q: "What was Bodhidharma's intention in coming from the west?"

A: "The cypress tree in the front yard". ${ }^{4}$

In addition to things that are real, some huatous employ things that are unreal. For example, there is a different answer to the same question presented in Gongan 1.

Gongan 2 Q: "What was Bodhidharma's intention in coming from the west?"

A: "Hair grown on an incisor-tooth". ${ }^{5}$

\section{Preliminary Remarks}

To the best of my knowledge, a limited number of modern scholars have provided a detailed explanation about why Chan masters used such huatous as "the cypress tree in the front yard" or, for that matter, what they could mean. ${ }^{6}$ So far, these huatous have been regarded as mere intellectual perplexity or as a skillful means to arrest discrimination and stimulate questioning. ${ }^{7}$ The following questions remain: What then, do Chan teachers intend to convey to their students with these specific things as

2 Wright (2000, p. 202). Yasutani also understands a gongan as the unerring absolute authority of the Buddha-Dharma (Yasutani 1996, p. 7).

3 The term, xiancheng gongan (hyeonseong gongan in Korean and genjō kōan in Japanese) has been variously translated as, "manifesting suchness", "the realized universe", "manifesting absolute reality", "the presencing of truth", or "Offenbarmachen des vollen Erscheinens". See Davis (2009, p. 254, n. 10). For the origin of xiancheng gongan, note YFChY 769,a28-b2: 現成公 案 不隔一絲毫普天匝地是一箇大解脫問與日月同明與虛空等量 若祖若佛無別 元由乃古乃今同一正見若是利根上智. See also Ishii (2005, pp. 97-101).

4 See WG, case 37: 趙州因僧問 “如何是祖師西來意”, 州云 “庭前柏樹子”.

5 ZhZhChY 365,b17: 問 “如何是祖師西來意”, 師云 “板齒生毛”.

6 Apropos the "cypress tree in the front yard" in the previous Gongan 1, Heine writes that "it is crucial to see that the cypress tree was emblematic in Chinese lore of longevity and loyalty" (Heine 2014, p. 29). Criticizing this position, Jorgensen argues that "the cypress was usually associated with death" (Jorgensen 2015, p. 2). He also maintains that "the cypress tree, if it was not used simply due to circumstances by Zhaozhou, but metaphorically, would not suggest longevity but rather that Bodhidharma came to China to die" (Jorgensen 2015, p. 2). Their analyses, however, are restricted to what the cypress tree itself means. Neither one mentions the multiplicity of different answers given to the same question, "what was Bodhidharma's intention in coming from the west?".

7 Note also Sharf (2010, p. 54). 
huatous? How are their students able to attain enlightenment from investigating the aforementioned gongans which, on the surface, seem to be irrelevant or ridiculous?

In Buddhism, there is another approach which employs specific things, real or unreal, as its major component, and this is Buddhist logic, which contrasts with Chan in many respects. In particular, in the three-part syllogism, which is constituted by the "proposition" (pakṣa, 宗), the "reason" (hetu, 因), and the "example" (drștānta, 喻), ${ }^{8}$ the last component consists of an appeal to specific things. These things have a purpose to verify a universal fact or truth.

The aim of this paper is to discuss certain individual gongans whose huatou is a specific thing, real or unreal. Among the two different understandings of gongan, which were introduced above, it focuses on a gongan which itself exposes reality as it is. Insomuch as the huatou of a gongan adopts a specific thing for disclosing a truth, it is identical in its fundamental structure with the drștanta of a three-part syllogism. By looking into how a specific thing as the drṣtānta establishes a general law in a three-part syllogism, I will seek to uncover what kind of truth might be revealed by a gongan whose huatou employs a specific object.

\section{The $\operatorname{drsțtanta~in~a~Three-Part~Syllogism~}$}

In the three-part syllogism of Dignāga (ca. 480-540), a pivotal figure in the development of Buddhist logic, the "example" (drsțtanta) is recognized in the two senses, namely an "example object" (-artha) and an "example statement" (-vacana) (see Katsura 2004, p. 170). The "example object" is that in which a "reason" is shown to be followed by a "property to be proved" (sādhya, 所立) or is shown to be absent in the absence of a "property to be proved" (See Katsura 2004, p. 145). It is made up of the following binary: what is similar and what is dissimilar. On the other hand, the "example statement" is that which presents an "example" together with a general law that is derived from our observations or experiences. It is formulated, thus, to indicate that the "reason" is inseparably related to the "property to be proved". Let us see what differentiates them in the following logical formula:

[proposition] Sound is impermanent.

[reason] Because it is produced.

[similar ex. statement $]^{9}$ Whatever is produced is impermanent, like a pot.

[dissimilar ex. statement] ${ }^{10}$ Whatever is permanent is not produced, like the ether. ${ }^{11}$

In this formula, the "reason" is the property of being produced (krtakatva) and the "property to be proved" is impermanence (anityatva). The "example object" here is, in the first instance, a pot (ghata), in which the property of being produced is shown to be followed by impermanence, and in the second instance, the ether ( $\bar{a} k \bar{a} s a)$, in which the absence of impermanence is shown to be followed by the absence of the property of being produced. The pot is denoted as a similar example, while the ether is denoted as a dissimilar example. The "example statement" in this logical formula comprises, on the other hand, the expressions that "whatever is produced is impermanent, like a pot" and "whatever is permanent is not produced, like the ether". The former is called positive concomitance (anvaya, 合), while the latter is called negative concomitance (vyatireka, 離). The role of the two examples in the positive and the negative concomitances is to reveal the pervasion (vyāpti) or the inseparable relation (avinābhāva) between the "reason" and the "property to be proved", here, the property of being produced and impermanence.

8 For more on the three-part syllogism and its elements, see Katsura (1998, pp. 265-69); Tachikawa (1971, pp. 113-18).

9 The "similar example statement" refers to the Sanskrit term, sapakșānugamavacana, which literally means the "statement in accordance with a similar instance".

10 The "dissimilar example statement" refers to the Sanskrit term, vyatirekavacana, which means the "statement of negative concomitance".

11 Cf. NP 141,6-9: anityaḥ śabda iti pakṣavacanam. krtakatvād iti pakșadharmavacanam. yat krtakam tad anityam dṛstam yathā ghatāadir iti sapakṣānugamavacanam. yan nityam tad akrtakam drștam yathākāśam iti vyatirekavacanam; YJL 11,b20-23: 聲無常者是立宗言. 所作性故者是宗法言. 若是所作見彼無常如瓶等者是隨同品言. 若是其常見非所作如空者是遠離言. 
Dignāga wanted to present both similar and dissimilar examples in order to induce the general proposition of pervasion. In any case, his use of the "example statement", whether similar or dissimilar, is to express the pervasion of the "reason" by the "property to be proved". Dharmakīrti (ca. 600-60), who further developed Dignāga's logic, laid emphasis on such characteristics of the "example statement" and adopted a new proof formulation that consists of the statements of the "pervasion" (vyāpti) and the "reason's being a property of the topic of a proposition" (pakșadharmatā). He and his followers used the formulation to affirm Buddhist truths such as the theory of momentariness.

[pervasion] Whatever is existent is momentary, like a pot.

[reason's being a property of the topic of a proposition] These things under debate are existent. ${ }^{12}$

In this logical formula, the "pervasion" encompasses all that is existent. Such pervasion is called "all-inclusive pervasion" (sarvopasaṃhāravyāpti). It is applied to everything, and demonstrates a general law i.e., here, momentariness. ${ }^{13}$ Therefore, a pot placed within the above "pervasion" (vyāpti) is an example that illustrates a truth (i.e., the truth of momentariness).

\section{The Three-Part Syllogism in the Buddhist Community of Tang and Song China}

Although the two-part syllogism was unknown to the Buddhist community of Tang and Song China, the three-part syllogism was widely used and was popular. Buddhist experts on the "science of reasons" (hetuvidyā, 因明), such as Xuanzang (玄牀, ca. 602-64), frequently used the three-part syllogism in a simplified form: its last element, drṣțānta, is embodied in an "example object" without presenting the positive and negative concomitances. ${ }^{14}$ For instance,

[proposition] The views of self do not take the real ātman as an object.

[reason] Because they have their [own] objects.

[example] Like the mind taking other things as its object. ${ }^{15}$

It is highly conceivable that the Chan masters in the time of Tang and Song were actually aware of the three-part syllogism. Mazu Daoyi (馬祖道一, ca. 709-88), the retrospective patriarch of the Hongzhou House (洪州宗), one of the five houses of the Chan school, tried to prove the nature of the body of Dharma (法身) by means of this logical formula.

[proposition] [The body of Dharma] neither abandons conditioned [dharmas] nor dwells in unconditioned [dharmas].

[reason] Because it does not dwell in any basis, in the case that conditioned [dharmas] are a function of unconditioned [dharmas] and unconditioned [dharmas] are a basis of conditioned [dharmas].

[example] Like the space that does not have any basis. ${ }^{16}$

12 Cf. HB 5*,19-20: yat sat tat sarvam kṣaṇikam, yathā ghațādayah. saṃś ca śabda iti; see also KSA 67,6: yat sat tat kṣaṇikam, yathā ghatah. santaś cāmī vivāadāspadībh ùtāh padārthāh; KBhA 1,8: yat sat tat kṣanikam, yathā jaladharah. santas tu bhāvā ime.

13 "All-inclusive pervasion" encompasses all existing things. Its components, the "reason" (hetu) and the "property to be proved" (sādhya) belong to everything. In the previous logical formula of Dharmakīrti and his followers, for instance, 'existence' and 'momentariness' are properties of all things. For more on this pervasion, see Funayama (2001, pp. 315-18); Shiga (2011, pp. 521-34).

14 This simplified form of the three-part syllogism is not a new innovation of East Asian Buddhism. It was already widely used in India, even around the time of Dignāga. For instance, see NP 143,16-17: nityah śabdo 'mūrtatvāt paramānuvat.

15 ChL 2,a6: 諸我見所緣實我 有所緣故 如緣餘心. For some more instances of the three-part syllogism, note ChL 1,c14-15: 餘行餘色亦非實我, 如虛空等, 非覺性故; ChL 3,a10-11: 彼所執非實德等應非離識有別自性, 非實攝故, 如石女兒; and ChL 3,a11-12: 非有實等應非離識有別自性, 非有攝故, 如空華等.

16 MDChG 812,b13-14: [法身]不盡有為 不住無為, 有為是無為家用 無為是有為家依 不住於依故, 云如空無所依. 
In addition, Yongming Yanshou (永明延壽, ca. 904-75), the $3^{\text {rd }}$ patriarch of the Fayan House (法眼宗), made good use of the three-part syllogism in his Zongiing $l u$. For instance,

[proposition] Mind must hold the image of an object.

[reason] Because it grasps an external thing.

[example] Like a mirror at the time of manifesting a face. ${ }^{17}$

Furthermore, there is a strong possibility that Dahui Zonggao (大慧宗杲, ca. 1089-163), who exerted a profound influence upon the Kanhua Chan, was conversant with this line of reasoning. Dahui enumerated the three-part syllogism i.e., the "proposition", the "reason", and the "example", in order to demonstrate the fact that the Mind (心) cannot, like the gem of Mani, be contaminated due to its original purity. ${ }^{18}$ Above of all, the celebrated gongan collection entitled the Biyan lu (碧蟩錄) begins with the sentence, "When you see smoke on the other side of a mountain, you immediately know there is fire" ${ }^{19}$ This is obviously a reference to the well-known illustration of a prototypical syllogism cited in ancient India.

\section{Specific Things as a huatou and Their Manifesting a Truth}

Even though it is fairly certain that some Chan masters were aware of the three-part syllogism, it is unclear whether they really adopted the idea of drștānta in their gongan formulations. However, it cannot be denied that specific things, real or unreal, are actually used as key phrases (huatou, 話頭) in the Chan dialogues. For instance, the "cypress tree in the front yard", previously mentioned, is an object that Chan masters utilized in their answer. At this point, my question is focused primarily on whether these things employed in gongans presuppose a general law as do those used in the above logical formulas. In the previous three-part syllogism discussed in page 3 of this paper, the "pot" is an example that reveals the impermanence of all conditioned things (samskrtadharma, 有爲法). If so, is the "cypress tree in the front yard" an example that is meant to illustrate a certain truth?

Chan masters use the term "original face" (benlai mianmu 本來面目) to describe the inherent state of enlightenment. ${ }^{20}$ As not having originated from and being free from the duality of subject and object, the "original face" is that which encompasses every existence. By way of illustration, let us look at the following gongan in the Biyan lu, which is a Chan dialogue between a monk and Zhaozhou.

Gongan 3 Q: "All things return to one; where does the one return?"

A: “When I was in Qing providence, I made a cloth shirt, which weighed seven pounds". ${ }^{21}$

According to the Japanese Zen master, Hakuin Ekaku (ca. 1685-768), author of a commentary on the Biyan lu, this form of questioning in the gongan is called a "wrapping up question", so called because the monk wants a definitive answer to the question: what is the ultimate point in which everything is included? (See Cleary 2000, p. 148). The "one" in the above question has other appellations such as Dharma realm (dharmadhātu, 法界), One mind (ekacitta, 一心), and Buddha nature (buddhadhātu, 佛性). ${ }^{22}$ Although diversely depicted in accordance with the various scriptural teachings, it expresses

17 ZL 799,a5-7: 心上必帶境之影像, 宗因云 心對外質, 同喻如鏡照面時.

18 Note DPChF 923,b15-17: 如清淨摩尼寶珠 置泥潦之中 經百千歲 亦不能染污, 以本體自淨故, 此心亦然.

19 BYL 140,a12: 第一則 垂示, “隔山見煙早知是火”.

20 The full sentence of benlai mianmu is: “What was your 'original face' before your parents conceived you (父母未生前 本來面 目)?" The "parents" allude to the duality of subject and object, etc. The term of benlai mianmu is best known in Case 23 of the gongan collection, Wumen guan (無門關), in which the sixth patriarch Huineng says, "not thinking of good, not thinking of evil, at this very moment, what is your 'original face'?". See WG 295,23: 不思善不思惡 正與麼時那箇是明上座本來面目.

21 BYL 181,c17-19: 擧 僧問趙州“萬法歸一一歸何處”, 州云 “我在靑州作一領布衫重七斤”.

22 For a breakdown of the different names related to the "one", see Buswell (1991, p. 335; 1992, pp. 121-22). From the beginning of Buddhism, a truth has been expressed in multiple ways. For instance, the Noble Truth of Suffering (duhkhasatya, 苦諦) has been configured as four aspects (ākāra): impermanence (anityatā, 無常), selflessness (nairātmya, 無我), suffering (duhkhatā, 
a Buddhist truth, constituting the fundamental principle of everything (Note Faure 1986, pp. 110-12; Buswell 1991, p. 341; Welter 2011, pp. 52-55).

In Gongan 3, Zhaozhou answers that the "one" returns to a "cloth shirt that weighed seven pounds". This means that the "shirt" here is not simply clothing perceived by ordinary people. Rather, it is a being or object that reveals an all-encompassing truth that the "one" illustrates. ${ }^{23}$ The aforementioned "cypress tree in the front yard" serves the same logical function as the "shirt" in the sense that it is a specific thing that enabled Chan teachers to provide an answer to the question, "What is Buddhist ultimate truth?". Therefore, the same can be said of the "cypress tree in the front yard": namely, from the enlightened teacher's perspective, it itself is that which manifests a truth.

\section{A huatou as a drșțānta}

Given that the "cypress tree in the front yard" uncovers a truth, it is worth asking what kind of truth it might express. Let us consider this issue by looking at one of the most popular concepts in the Chan teachers' repertoire, the Dharma realm. According to Huayan Buddhism, everything is the full revelation of the body of the cosmic Buddha. ${ }^{24}$ A real thing in the actual world is nothing other than a Dharma body (dharmakāya, 法身). ${ }^{25}$ Each Dharma body is that which manifests the true reality of the Dharma realm. ${ }^{26}$ For instance, a pine tree reveals its true reality; a chestnut tree reveals its true reality. ${ }^{27}$ This Huayan thought is well stated in Chan master Mazu's following description: "There is no place to stand where one leaves the truth. The very place one stands on is the truth; it is all one's being. If that is not so, then who is that? All dharmas [things] are Buddhadharmas and all dharmas never leave suchness. Whether walking, standing, sitting, or reclining, everything is always the inconceivable function [of suchness]. The scriptures say that a Buddha is everywhere" ${ }^{28}$

Insomuch as the "cypress tree in the front yard" is a real thing (or object), it is a Dharma body from the Huayan standpoint, a lens through which Chan masters see this world. ${ }^{29}$ Therefore, this "cypress tree" is a thing which manifests the true reality of the Dharma realm. In other words, the "tree" is that in which the property of "being a Dharma body" is shown to be followed by the property of "revealing the true reality of the Dharma realm". Since the "cypress tree in the front yard" is an instance which presents a positive concomitance (anvaya, 合)-i.e., "Whatever is a Dharma body reveals the true reality of the Dharma realm"-it is entirely plausible to propose that Zhaozhou's gongan is expressed in the following three-part syllogism, a logical formula which was already known in the China of his time.

[proposition] A real thing reveals the true reality of the Dharma realm.

[reason] Because it is a Dharma body.

[similar ex. statement] Whatever is a Dharma body reveals the true reality of the Dharma realm, like the cypress tree in the front yard. ${ }^{30}$

苦), and emptiness (śūnyatā, 空). By way of example, impermanence conforms to the truth that all conditioned things are impermanent; selflessness confirms to the truth that all conditioned things are selfless; etc. For more on this, see Conze (1962, pp. 34-39).

23 See YFChY 769,a28-29: 現成公案 不隔一絲毫普天匝地 是一箇大解脫門. Note also, Roshi Taisen Deshimaru's statement that “all phenomena of our life become a truth" (Coupey 1979, p. 21).

24 See DGHJ 454,c2-3: 清淨妙法身 應現種種形唒如大幻師 所樂無不現 and DGHJ 486,b18-19: 三世一切佛法身悉清淨隨其所 應化 普現妙色身.

25 Note BYL 177,b28: 法身覺了無一物.

26 DGHJ 39,b28: 華藏世界所有塵一一塵中見法界.

27 See BDChR 758,a26-b4: 法界佛無處不至故者一塵法界松木法界 栗木法界乃至十方三際虛空法界 總是佛身所謂真如 前際 不滅 後際不生 現在不動. 如來亦爾 過去無隇未來無生 現今無動 無形無相如虛空界 不可量故. 百千萬劫已說 今說當說 終不 可盡 無有邊祭故 日法界佛也.

28 Requoted from Poceski (2007, p. 184).

29 According to Yumen, every phenomenon in this world is a Dharma body. Note YWChG 559,a15-16: 一切聲是佛聲一切色是 佛色 盡大地是法身. See also Takasaki and Umehara (1997, pp. 39-40).

30 It is obvious that Dharmakirti's logical formula was not used in China in the period of Tang and Song dynasties. For this reason, I express this gongan in the format of the three-part syllogism. Since the truth the gongan implies is all-inclusive, however, it is better to be expressed in the two-part syllogism. 
The question in aforementioned Gongan 1 i.e., "what was Bodhidharma's intention in coming from the west?" appears a few times in the Zhaozhou lu. On each occasion, Zhaozhou's answer is different. Sometimes, it is "bed legs"; 31 at other times it is: "now, I am washing my feet". ${ }^{32}$ Given that there are several different answers to the same question, we can assume that the Chan master's focus is not the "cypress tree in the front yard" itself. Rather, it is the fact that from his fully enlightened perspective, everything in this world is a Dharma body. Consequently, whether it is "bed legs" or the "act of washing feet", there is no difference, since the truth that emanates from them reveals the true reality of the Dharma realm. Hence,

[proposition] A real thing reveals the true reality of the Dharma realm.

[reason] Because it is a Dharma body.

[similar ex. statement] Whatever is a Dharma body reveals the true reality of the Dharma realm, like the cypress tree in the front yard, and so on. ${ }^{33}$

As shown in the previous gongans, many key phrases (huatou, 話頭) are drawn from real empirically observable things. However, some are drawn from unreal or merely hypothetical instances. For example, the "hair grown on an incisor-tooth" stated in Gongan 2 does not exist anywhere in the world. ${ }^{34}$ The student's question is the same in Gongan 1 and Gongan 2. By placing these two dialogues together in a logical formula, we can see that the "hair grown on an incisor-tooth" exactly corresponds to a "dissimilar example" in the three-part syllogism:

[proposition] A real thing reveals the true reality of the Dharma realm.

[reason] Because it is a Dharma body.

[pervasion] Whatever is a Dharma body reveals the true reality of the Dharma realm, like the cypress tree in the front yard.

[reason's being a property of the topic of a proposition] The things that the teacher and the student are seeing together are a Dharma body.

The same truth can be expressed in various ways. According to the Dasheng qixin lun 大乘起信論, all things are nothing other than One mind (note DQL 576,a10-13: 是故一切法從本已來 離言說相虐名字相離心緣相 畢竟本等 無有變異 不可破 壞唯是一心故名具如). Using the concept of One mind, it may be stated in the following logical formula:

[pervasion] Whatever is a phenomenon (dharma, 法) is the manifestation of One mind, like the cypress tree in the front yard.

[reason's being a property of the topic of a proposition] The things that the teacher and the student are seeing together are a phenomenon.

31 See ZhZhChY 364,a30: 問 “如何是祖師西來意”師云 “床腳”. In BYL, there are more examples of gongan whose huatou presents a real thing: “What is Buddha?" “Three catties of flax." (Case 12: 僧問東山“如何是佛”山云“麻三厅”); “What is the Deva school?" “A silver bowl full of snow." (Case 13: 僧問巴陵“如何是提婆宗”巴陵云 “銀椀裏盛雪”); “What is the pure Dharma body?" “A flowering hedge.” (Case 39: 僧問雲門 “如何是淸淨法身” 門云 “花樂欄”); “What is a talk beyond Buddhas and patriarchs?”“A piece of cake." (Case 77: 僧問雲門“如何是超佛超租之談” 門云“餬餅”).

32 See ZhZhChY 369,c26-27: 師因到臨濟方始洗 臨濟便問 “如何是祖師西來意”師云 “正值洗腳”. For more on huatous that present a specific act, see BYL, Case 19: “Whenever a question was asked to Master Judi, he just raised a finger" (俱胝和尚 凡 有所問 “只㹂一指”); Case 32: “An elder monk asked Linji: What is the great meaning of the Buddha's teaching? Getting off his meditation seat, Linji grabbed the monk and gave him a slap, then pushed him away” (定上座問臨濟如何是佛法大義 濟“下禪 床摛住 與一掌 便托開”).

33 Here, "and so on" is equivalent to Sanskrit word "ādi" which is often used in the three part-syllogism in order to imply that there are many examples (drșțānta, 喻). For instance, see the part of NP 141.7-8: yat krtakam tad anityam dṛ̦tam yathā ghat âdir iti.

34 For more on huatous that depict an unreal thing, see SYYSH: "What is the place from which all Buddhas come?" "The East Mountain walking on the water." (Case 1034: 730,a15-16: 雲門因僧問 “如何是諸佛出身處” 師云 “東山水山行”); “What is the teaching of your tradition?" "An iron hen which, sitting on her eggs, goes back to the Milky Way and a rabbit in the moon which, being with her young, enters into the Jami palace.” (Case 1173: 797,a21-23: 洪州鳳棲山 同安丕禪師因僧問 “如 何是和尚家風”師日 “金雞抱子歸霄漢玉鬼懷胎入紫微”); “What is the business surpassing the stage of a Buddha?” “The sun and the moon rising from a Chan master's stick." (Case 1283: 847,c19-21: 僧云 “如何是佛向上事” 師云 “柱杖頭上挑日 月”). See also Kim (2010, pp. 1217, 1191, 1251). Note also GYChCh 709, a7: “What is the self before the eons of nothingness?" “Blood dripping from a mud cow.” (“如何是空劫已前自己” 旉卓主丈一下云 金剛喫鐵棒 “泥牛眼出血”). 
[similar ex. statement] Whatever is a Dharma body reveals the true reality of the Dharma realm, like the cypress tree in the front yard, and so on.

[dissimilar ex. statement] Whatever does not reveal the true reality of the Dharma realm is not a Dharma body, like the hair grown on an incisor-tooth.

To the question, "what is the Buddha's teaching that Bodhidharma wanted to transmit?", whether the answer is the "cypress tree in the front yard" or the "hair grown on an incisor-tooth", it does not simply refer to a certain existence or non-existence. ${ }^{35}$ As can be seen from the above logical formula, the real intention of the teacher lies in encouraging the student to see the pervasion immanent within the dictum: "Whatever is a Dharma body reveals the true reality of the Dharma realm"; or, conversely, the counter-pervasion that "whatever does not reveal the true reality of the Dharma realm is not a Dharma body". ${ }^{36}$ This demonstrates that just as the "pot" or the "ether" in Dignāga's three-part syllogism implies a general law, so does the "cypress tree in the front yard" or the "hair grown on the incisor-tooth" in Zhauzhou's gongans.

As the two statements of similar and dissimilar examples are logically equivalent in Buddhist logic, so too are those of key phrases that are expressive of the real and the unreal in gongans. Yuanwu Keqin (園悟克勤, ca. 1063-135), compiler of the Biyan lu, seemed to know this well.

A monk asked Yunmen, "What is the place from which all Buddhas come?" Yunmen answered, "The East Mountain walks on the water". However, if I were asked the same question, I would say, "As a fragrant breeze comes from the south, a chilly wind blows through the main hall of a temple". ${ }^{37}$

The "East Mountain walking on the water" is self-evidently absurd, and so, it is an instance of what is unreal. On the other hand, a "chilly wind blowing through the main hall of a temple as a fragrant breeze comes from the south" is plausible enough, and there can indeed be such a real instance. The questions, "what was Bodhidharma's intention in coming from the west?" and "what is the place from which all Buddhas come?" are, thus, the same in the end. They both ask what Buddhist truth is. If we examine the gongans of Yunmen and Yuanwu from the perspective of a logical formula, the former corresponds to a dissimilar example, while the latter is a similar example.

[proposition] A real thing reveals the true reality of the Dharma realm.

[reason] Because it is a Dharma body.

[similar ex. statement] Whatever is a Dharma body reveals the true reality of the Dharma realm, like a chilly wind blowing through the main hall of a temple as a fragrant breeze comes from the south.

[dissimilar ex. statement] Whatever does not reveal the true reality of the Dharma realm is not a Dharma body, like the East Mountain walking on the water.

What Yuanwu wants to emphasize here is not whether Yunmen's answer is right or wrong. He only means to say that his answer is more effective than Yunmen's in guiding a student, who is enveloped in the darkness of ignorance, along the right path. This is because he presented an actual event relatable to an ordinary experience, whereas Yunmen did not. This explains why real, phenomenal things greatly outnumber unreal, hypothetical things in the framing of the key phrases of gongans.

35 There is a gongan which clearly shows this point, employing a "cow's horns" and a "rabbit's horns". See SYYSH 642,c4-6: (Case 892) 曹山因僧問 郎心㴧佛郎不問如何是非心非佛師云 “鬼角不用無 牛角不用有”.

36 As a truth, the pervasion and the counter-pervasion are well expressed in DGHJ 444,a9-10: 法身眞實相於實知眞實非實知 非實.

37 See DPChF 883,a15-18: “僧問雲門 如何是諸佛出身處門云 東山水上行 若是天寧不然如何是諸佛出身處 薰風自南來殿閣生 微向”. 


\title{
8. Concluding Remarks
}

Essentially, gongans are based on the difference of perspectives between Chan teachers and students. Teachers represent the realm of nirvāna, while students represent the realm of emotional afflictions (kleśa). Teachers create gongans, employing various methods to guide students to enlightenment which they, the teachers, have already experienced for themselves. ${ }^{38}$ In this respect, there is a strong possibility that Chan teachers, who regarded simplicity and shortcuts (徑截) as the highest of virtues, showed a special interest in a logical formula (prayoga) of Buddhist logic, which was designed to succinctly express a truth or fact. As noted above, the way that a gongan employs a specific thing, whether real or unreal, as a huatou is structurally quite similar to the manner in which the three-part syllogism employs it as a drștānta. In both cases of the huatou and the drștānta, the specific thing illustrates a truth (or fact). The main difference between them can be described thus: the huatou utilizes a specific thing to induce a realization of a truth yet to be revealed, whereas the drștānta utilizes a specific thing to verify a truth completely revealed.

Funding: This work was supported by the Academy of Korean Studies (KSPS) Grant funded by the Korean Government (MOE): AKS-2012-AAZ-2102.

Conflicts of Interest: The author declares no conflict of interest.

\author{
Abbreviations \\ BDChR Bupgye dogi chongsu rok 法界圖記丵髓錄. In T no. 1887B, 45: 716,a21-767,c20. \\ BYL Biyan lu 碧嚴錄. In T no. 2003, 48: 139,a1-225,c14. \\ ChL Chengweishilun 成唯識論. In T no. 1585, 31: 1,a1-60,a12 \\ DGHJ Dafang guangfo huayan jing 大方廣佛華嚴經. In T no. 278, 9: 395,a1-788,b9. \\ DPChF Dahui Pujue chanshi fayu 大慧普覺禪師法語. In T no. 1998A, 47: 890,a1-943,b4. \\ DQL Dasheng qixin lun 大乘起信論. In T no. 1666, 32: 575,a1-583,b17. \\ GYChCh Gaofeng Yuanmiao chanshi chanyao 高峰原妙禪師禪要. In X no. 1401, 70: 702,a1-713,a13. \\ HB Hetubindu of Dharmakīrti, part I, ed. E. Steinkellner. Wien: Österreichische Akademie der \\ HBJ Wissenschaften, 1967. \\ $\mathrm{J} \quad$ Jiaxing jing 嘉興藏 \\ KBhA Kṣaṇabhanggādhyāya of Jñānaśrīmitra. In A. Thakur, ed. 1987. Jñānaśrīmitranibandhāvalih: \\ 1-159. Patna: K. P. Jayaswal Research Institute. \\ KSA Kṣaṇabhñgasiddhi-Anvayātmikā of Ratnakīrti. In A. Thakur, ed. 1975. Ratnakīrtinibandhāvalih: \\ 67-82. Patna: K. P. Jayaswal Research Institute. \\ MDChG Mazu Daoyi chanshi guanglu 馬祖道一禪師廣錄. In X no. 1321, 69: 809,a1-816,b18. \\ NP Nyāyapraveśa of Śankarasvāmin. In Tachikawa (1971, pp. 140-44). \\ SYYSH Seonmun yeomsong yeomsong seolhwa hoebon 禪門拈頌拈頌說話會本. In HBJ, vol. 5: \\ $\mathrm{T} \quad$ 1,a1-925,c5. \\ WG Wumen guan 無門關. In T no. 2005, 48: 292,a23-299,c25. \\ X Xuzang jing 續藏經 \\ YFChY Yuanwu Foguo chanshi yulu 圓悟佛果禪師語錄. In T no. 1997, 47: 713,b19-810,c29. \\ YJL Yinming juchengli lun 因明入正理論. In T no. 1630, 32: 11a-12c. \\ YWChG Yumen Wenyen chanshi guanglu雲門門偃禪師廣錄. In T no. 1988, 47: 544,c23-577,c29. \\ ZhZhChY Zhaozhou Zhenji chanshi yulu 趙州眞際禪師語錄. In J no. B137, 24: 357,a1-372,b15. \\ ZL Zongjing $l u$ 宗鏡錄. In T no. 2016, 48: 415,a1-957,b16.
}

38 The encounter dialogues between Chan masters and students played a crucial role in the development of Chan discourse. For their significance as the basic literary unit of the great majority of gongan cases, see Yanagida (1983, pp. 192-94); Heine (2000, pp. 139-42). 


\section{References}

Buswell, Robert E., Jr. 1991. The "Short-cut" Approach of K'an-hua Meditation: The Evolution of a Practical Subitism in Chinese Ch'an Buddhism. In Sudden and Gradual Approaches to Enlightenment in Chinese Thought. Edited by Peter N. Gregory. Delhi: Motilal Banarsidass, pp. 321-77.

Buswell, Robert E., Jr. 1992. Tracing Back the Radiance: Chinul's Korean Way of Zen. Honolulu: University of Hawai'i Press.

Thomas Cleary, trans. 2000, Secrets of the Blue Cliff Record. Boston: Shambhala.

Conze, Edward. 1962. Buddhist Thought in India. London: George Allen \& Unwin.

Coupey, Philippe, ed. 1979. The Voice of the Valley: Zen Teachings by Roshi Taisen Deshimaru. Indianapolis and New York: The Bobbs-Merrill Company, Inc.

Davis, Bret W. 2009. The Presencing of Truth. In Buddhist Philosophy: Essential Readings. Oxford: Oxford University Press, pp. 251-59.

Faure, Bernard. 1986. The Concept of One-Practice Samādhi in Early Ch'an. In Traditions of Meditation in Chinese Buddhism. Edited by Peter N. Gregory. Honolulu: University of Hawai'i Press, pp. 99-128.

Funayama, Toru. 2001. On the Date of Vinītadeva. In Le Parole e i Marmi. Edited by Raffaele Torella. Roma: Istituto Italiano per L'africa e L'oriente, pp. 309-25.

Heine, Steven. 2000. Visions, Divisions, Revisions: The Encounter between Iconoclasm and Supernaturalism in Kōan Cases about Mount Wu-t'ai. In The Kōan: Texts and Contexts in Zen Buddhism. Edited by Steven Heine and Dale S. Wright. Oxford: Oxford University Press, pp. 137-67.

Heine, Steven. 2014. Zen Kōans. Dimensions of Asian Spirituality Series. Honolulu: University of Hawai'i Press.

Ishii, Seijun. 2005. Genjōkōan no imisuro mono 現成公案の意味するもの. Komajawa Daigaku Bukkyōgakugu Ronshū 36: 97-110.

Jorgensen, John. 2015. Jorgensen on Heine, 'Zen Kōans'. In H-Buddhism. Available online: https://networks.h-net. org/node/6060/reviews/69377/jorgensen-heine-zen-koans (accessed on 22 August 2020).

Katsura, Shoryu. 1998. Indojin no Ronrigaku. Tokyo: Cūou Kouronsha.

Katsura, Shoryu. 2004. The Role of dṛ̦țānta in Dignāga's Logic. In The Role of the Example (dṛștānta) in Classical Indian Logic. Wien: Arbeitskreis für Tibetische und Buddhistische Studien Universität Wien, pp. 135-73.

Kim, Hee-Jin. 1985. The Reason of Words and Letters: Dōgen and Kōan Language. In Dōgen Studies. Edited by William R. LaFleur. Honolulu: University of Hawai'i Press, pp. 54-82.

Kim, Younguk, trans. 2010, Jeongseon Gongan Jip. 精選公案集. Seoul: The Jogye Order of Korean Buddhism.

Nishijima, Gudo, and Cross Chodo, transs. 2007, Shōbōgenzō: The True Dharma-Eye Treasury. Berkeley: Numata Center for Buddhist Translation and Research, vol. 1.

Poceski, Mario. 2007. Ordinary Mind as the Way: The Hongzhou School and the Growth of Chan Buddhism. New York: Oxford University Press.

Sharf, Robert. 2010. How to Think with Chan Gongans. In Ganhwa-seon, Illuminating the World. Seoul: Dongguk Institute for Buddhist Studies Research, pp. 49-77.

Shiga, Kiyokuni. 2011. Remarks on the Origin of All-Inclusive Pervasion. Journal of Indian Philosophy 39: 521-34. [CrossRef]

Tachikawa, Musashi. 1971. A Sixth Century Manual of Buddhist Logic: A Translation of Nyāyapraveśa. Journal of Indian Philosophy 1: 111-45. [CrossRef]

Takasaki, Jikidō, and Takeshi Umehara. 1997. Kobutsu no Manebi: Dōgen. Tokyo: Kadokawa Shoten.

Welter, Albert. 2011. Yongming Yanshou's Conception of Chan in the Zongiing lu. Oxford: Oxford University Press.

Wright, Dale S. 2000. Kōan History: Transformative Language in Chinese Buddhist Thought. In The Kōan: Texts and Contexts in Zen Buddhism. Edited by Steven Heine and Dale S. Wright. Oxford: Oxford University Press, pp. 200-12.

Yanagida, Seizan. 1983. The 'Recorded Sayings' Texts of Chinese Chan Buddhism. In Early Ch'an in China and Tibet. Edited by John R. McRae. Berkeley: Berkeley Buddhist Studies Series, pp. 185-205.

Yasutani, Hakuun. 1996. Flowers Fall: A Commentary on Zen Master Dōgen's Genjōkōan. Boston: Shambala Publications.

(C) 2020 by the author. Licensee MDPI, Basel, Switzerland. This article is an open access article distributed under the terms and conditions of the Creative Commons Attribution (CC BY) license (http://creativecommons.org/licenses/by/4.0/). 